\title{
Rejoinder: Four-series concept of the Cambrian has a long history
}

\author{
SHANCHI PENG \& LOREN E. BABCOCK
}

PENG, S.C. \& BABCOCK, L.E. 2012. Rejoinder: Four-series concept of the Cambrian has a long history. Bulletin of Geosciences 87(3), 629-632. Czech Geological Survey, Prague. ISSN 1214-1119. Manuscript received April 4, 2012; published online May 23, 2012; issued September 28, 2012.

Shanchi Peng, State Key Laboratory of Palaeobiology and Stratigraphy, Nanjing Institute of Geology and Palaeontology, Chinese Academy of Sciences, Nanjing, China 210008; scpeng@nigpas.ac.cn • Loren E. Babcock, School of Earth Sciences, The Ohio State University, 125 South Oval Mall, Columbus, OH 43210, USA and Department of Geology, Lund University, Lund University, Sölvegatan 12, SE-223 62 Lund, Sweden; loren.babcock@geol.lu.se

In an earlier paper in this journal, we (Peng \& Babcock 2011) provided a brief synopsis of progress made by the International Subcommission on Cambrian Stratigraphy (ISCS) toward defining and ratifying globally applicable series and stages of the Cambrian System. Among the topics reviewed was the four-series, ten-stage model of the Cambrian voted into practice by the Subcommission (Peng \& Babcock 2005, Babcock et al. 2005). Landing (2012) pointed out that in our review (Peng \& Babcock 2011) we neglected to cite his suggestions (Landing 1998a, 1998b) that the Cambrian could be subdivided into four parts, and notes that the origin of the four-part concept evolved from studies in Avalonian sequences. In our review paper, we acknowledged that a four-fold subdivision of the Cambrian System had been discussed by various workers and, in the interest of brevity, exemplified this by "(e.g., Palmer 1998)". Landing's accompanying commentary gives us an opportunity to explain why Palmer's (1998) work was selected as an example. It also gives us the opportunity to provide a more complete history of the concept of subdividing the Cambrian into four series.

\section{Subdivision of the Cambrian in North America}

Palmer (1998), in an overview paper, proposed subdividing the Cambrian of Laurentia into four regional series (Begadean, Waucoban, Lincolnian, and Millardan) and six stages. This work was the most complete chronostratigraphic subdivision for Laurentia at the time, and it provided the structure and format for subdividing the Cambrian in other regions, which ultimately gave way to the plan adopted by the ISCS. Although it was not the first time that a four-series subdivision of the Cambrian was proposed, it was quite simply the most straightforward and influential of the earlier proposals. It became the template for the Geological Society of America's 1999 Geologic Time Scale (Palmer \& Geisman 1999), and later appeared in chapters on the Cambrian Period in such widely used publications as A Geologic Time Scale 2004 (Shergold \& Cooper 2004), The Concise Geologic Time Scale (Peng \& Babcock 2008) and The Geologic Time Scale 2012 (Peng et al. 2012).

The concept of a four-part Cambrian has a long history. Informal discussions of the possibility of erecting a four-series subdivision were taking place within the community of Cambrian scientists by at least the 1990s, and more formal presentations of the concept were developed at the third ISCS field meeting, organized by Ed Landing, which centered around field sites in Avalonian North America (southeastern Newfoundland and New Brunswick, Canada) in 1997. The field guide for that meeting was copyrighted in 1997 and published in 1998 as New York State Museum Bulletin 492 (Landing \& Westrop 1998). Another result of the field meeting in eastern Canada was a theme issue of Canadian Journal of Earth Sciences (Vol. 35, No. 4) entitled "Cambrian Subdivisions and Correlations", edited by Ed Landing. The theme issue contained Palmer's (1998) paper, which was also mentioned in the introduction (Landing 1998b).

We deemed it sensible to cite Palmer's (1998) seminal paper as an example of a proposal to subdivide the Cambrian into four series because it was the first clear, concise articulation of the idea, and it was illustrated with a chart that was consistent with the text of the proposal. In addition to four series, Palmer (1998) defined new stages or applied ones defined earlier (Ludvigsen \& Westrop 1985).

In contrast to Palmer's uncomplicated, straightforward proposal, Landing (1998a), in the introduction to the guidebook for the 1997 ISCS field conference, suggested that the Cambrian could be subdivided into four series grouped within three subsystems. This idea, if followed, would maintain use of the terms "Lower", "Middle", and "Upper" Cambrian. Stages were not included in the scheme. We should emphasize that this work was a general discussion of how to possibly divide the Cambrian rather than a serious proposal for establishing four global series. The four series he used are still regarded as regional subdivisions of 
the Avalonian succession. Landing's (1998a) commentary was accompanied by another paper (Landing \& Westrop 1998) illustrating the concept of four regional series for Avalonian North America. In a diagram of the stratigraphy of southeastern Newfoundland, Landing \& Westrop (1998, fig. 3) showed four series, Placentian, Branchian, Acadian, and Merionethian, grouped into three larger subdivisions, Lower Cambrian (comprising the Placentian and Branchian series), Middle Cambrian (comprising and synonymous with the Acadian Series), and Upper Cambrian (comprising and synonymous with the Merionethian Series). The stratigraphic rank of the terms Lower, Middle, and Upper Cambrian subdivisions was not discussed, but placement of these terms in a column below the Lower Ordovician, which is of series-level rank, implies that they could be treated as series rather than as subsystems.

In introducing the theme issue of Canadian Journal of Earth Sciences on Cambrian subdivisions and correlations, Landing (1998b) acknowledged Palmer's (1998) proposal of internally consistent regional series and stages for the Cambrian. He compared Palmer's concepts of the Begadean and Waucoban series to his own concept of the Lower Cambrian and referred to the Lower Cambrian as a "subsystem-level division ... composed of a pre-trilobitic and a trilobite-bearing Lower Cambrian series".

In short, rather than proposing a straightforward four-part subdivision of the Cambrian, Landing (1998a, b) advocated a three/four-part subdivision. In most subsequent work (e.g., Landing 2007; Landing et al. 2009, 2010, 2012; Landing \& MacGabhann 2010; Landing 2011, 2012) he has fairly consistently referred to a three-part subdivision of the Cambrian into Lower, Middle, and Upper parts, or a three/four-part subdivision with the Lower Cambrian embracing the Placentian and Branchian intervals. This approach contradicts the proposal for subdividing the Cambrian into four series and ten stages (Peng 2004) approved by Voting Members of the ISCS in 2005 (Babcock et al. 2005, Peng \& Babcock 2005). The ratified or suggested boundaries of the four global series (two of which are still undefined) do not correspond exactly to the boundaries of the Placentian, Branchian, Acadian, and Merionethian Series used regionally for Avalon (Peng \& Babcock 2008, Peng et al. 2012). The ISCS has not ratified any proposal to group the four Cambrian series into three subsystems, so the terms "Lower", "Middle", and "Upper" Cambrian do not have any formal status except in historic or regional applications.

\section{Pre-1990 concepts of a four-part Cambrian System}

A number of papers either alluding to or expressly discussing subdivision of the Cambrian System into four parts were published prior to the time that the ISCS began discussions of formalizing the idea. Concepts of a quadripartite subdivision arose iteratively as major studies were published on the strata of Avalonian North America, Siberia, China, and Laurentian North America.

The concept of a four-series Cambrian seems to have originated with George F. Matthew, who developed the idea from study of stratigraphic sequences in Avalonian North America nearly a century before the 1997 ISCS field conference in eastern Canada. Matthew (1890, 1899a-d) proposed a sub-trilobitic Paleozoic series, the Etcheminian Series, for the Avalonian region. The Etcheminian Series yields trace fossils and small shelly fossils (SSFs), and corresponds roughly to the Terreneuvian Series of current global usage. If we follow Landing (2012) in recognizing that the Avalon sequence includes the Placentian (Landing et al. 1989) and Branchian (Landing 1992) series, plus the traditional Middle and Upper Cambrian, then Matthew's Etcheminian Series added to the then-contemporary Lower, Middle, and Upper Cambrian meant that he likewise envisioned the lowermost Paleozoic (= Cambrian) as comprising four series.

Other early work in Siberia, China, and Laurentian North America also point to the conclusion that workers recognized the possibility that the Cambrian could be divided into four major intervals that included a pre-trilobitic series or stage. A pre-trilobitic stage, the Tommotian Stage, was recognized from Siberia (Rozanov \& Missarzhevsky 1966), and a pre-trilobitic stage, the Meishucunian Stage, was recognized from South China (Qian 1977). Both regional stages are characterized by assemblages of SSFs and archaeocyaths. The Tommotian Stage is equivalent to part of the Terrenuevian Series, and the Meishucunian Stage corresponds fairly closely to the Terreneuvian. Fritz (1992) used a four-series approach to subdividing the Cambrian by borrowing the term "Placentian Series" from Avalonian regional usage and adding it to the Waucoban Series to form a downwardly expanded Laurentian Lower Cambrian. Subdivision of the Russian, Chinese, and Laurentian Lower Cambrian into two parts, to which were added various regional formulations of Middle and Upper Cambrian, rendered the Cambrian a system comprising four major subdivisions similar to Landing's (1998a, b) concept.

\section{Closing remarks and acknowledgments}

We would like to acknowledge the efforts of the many colleagues within the Cambrian community who have contributed ideas and data toward formal chronostratigraphic subdivision of the Cambrian System. We did not intend to cause affront by omitting specific statements of the contributions of each individual either in our earlier paper (Peng 
\& Babcock 2011) or here. Likewise, we did not intend to undervalue the importance of studies conducted in Avalon, Siberia, South China, or any other Cambrian region toward the ongoing synthesis. We apologize to the many persons whose important papers were not cited in our brief reviews. We would like to thank the editor of this issue for the opportunity to respond to the accompanying paper by Landing.

\section{References}

Babcock, L.E., Peng, S.C., Shergold, J.H. \& Geyer, G. 2005. Changing perspectives on Cambrian chronostratigraphy and progress toward subdivision of the Cambrian System. Geosciences Journal 9, 101-106. DOI 10.1007/BF02910572

FrITZ, W.H. 1992 (also dated 1991). Cambrian assemblages, 155-184. In Gabrielse, H. \& Yorath, C.J. (eds) Geology of the Cordilleran Orogen in Canada. Geological Survey of Canada, Geology of Canada 4 (also Geology of North America G-2, Geological Society of America).

LANDING, E. 1992. Lower Cambrian of southeastern Newfoundland: epeirogeny and Lazarus faunas, lithofacies-biofacies linkages, and the myth of a global chronostratigraphy, 283-309. In LipPs, J. \& Signor, P.W. (eds) Origins and Early Evolution of Metazoa. Plenum Press, New York.

LANDING, E. 1998a. Avalon 1997 - A pre-meeting viewpoint, 1-3. In Landing, E. \& Westrop, S.R. (eds) Avalon 1997 The Cambrian Standard. New York State Museum Bulletin 492.

LANDING, E. 1998b. Cambrian subdivisions and correlations: Introduction. Canadian Journal of Earth Sciences 35, 321-322. DOI 10.1139/e98-013

LANDING, E. 2007. East Laurentia 2007 - A pre-meeting statement, 3-4. In LANDING, E. (ed.) Ediacaran-Ordovician of East Laurentia - S. W. Ford Memorial Volume. $12^{\text {th }}$ International Field Conference of the Cambrian Stage Subdivision Working Group. New York State Museum Bulletin 510.

LANDING, E. 2011. Time-specific black mudstones and global hyperwarming on the Cambrian-Ordovician slope and shelf of the Laurentia palaeocontinent. Palaeogeography, Palaeoclimatology, Palaeoecology. DOI 10.1016/j.palaeo.2011.09.005

LANDING, E. 2012. Correction: proposal of the four global series of the Cambrian. Bulletin of Geosciences 87(3), 625-627. DOI 10.3140/bull.geosci.1332

Landing, E. \& MacGabHann, B.A. 2010. First evidence for Cambrian glaciation provided by sections in Avalonian New Brunswick and Ireland: Additional data for Avalon-Gondwana separation by the earliest Palaeozoic. Palaeogeography, Palaeoclimatology, Palaeoecology 285, 174-185. DOI 10.1016/j.palaeo.2009.11.009

Landing, E., Myrow, P., Benus, A.P. \& Narbonne, G.M. 1989. The Placentian Series: appearance of the oldest skeletalized faunas in southeastern Newfoundland. Journal of Paleontology 63, 739-769.
LAnding, E., Amati, L. \& Franzi, D.A. 2009. Epeirogenic transgression near a triple junction: The oldest (latest early-middle Cambrian) marine onlap of cratonic New York and Quebec. Geological Magazine 146, 552-566.

DOI $10.1017 / \mathrm{S} 0016756809006013$

Landing, E., English, A. \& KePpie, J.D. 2010. Cambrian origin of all skeletalized metazoan phyla - Discovery of Earth's oldest bryozoans (Upper Cambrian, southern Mexico). Geology 38, 547-550. DOI 10.1130/G30870.1

Landing, E., Adrain, J.M., Westrop, S.R. \& Kröger, B. 2012. Tribes Hill-Rochdale formations in east Laurentia: proxies for Early Ordovician (Tremadocian) eustasy on a tropical passive margin (New York and west Vermont). Geological Magazine 149, 93-123. DOI 10.1017/S0016756811000598

LANDinG, E. \& Westrop, S.R. (eds) 1998 (copyrighted in 1997). Avalon 1997 - The Cambrian Standard. New York State Museum Bulletin 492, 1-92.

Ludvigsen, R. \& Westrop, S.R. 1985. Three new Upper Cambrian stages for North America. Geology 13, 139-143. DOI 10.1130/0091-7613(1985)13<139:TNUCSF>2.0.CO;2

Matthew, G.F. 1890. On Cambrian organisms in Acadia. Transactions of the Royal Society of Canada 7(4), 135-162.

Matthew, G.F. 1899a. A Palaeozoic terrane beneath the Cambrian. Annals of the New York Academy of Sciences 12, 41-56. DOI 10.1111/j.1749-6632.1899.tb54983.x

Matthew, G.F. 1899b. The Etcheminian fauna of Smith Sound, Newfoundland. Transactions of the Royal Society of Canada, Series 2, 5(4), 97-123.

Matthew, G.F. 1899c (issued in 1902). Preliminary notice of the Etcheminian fauna of Newfoundland. Bulletin of the Natural Historical Society of New Brunswick 18(4), 189-197.

Mathew, G.F. 1899d (issued in 1902). Preliminary notice of the Etcheminian fauna of Cape Breton. Bulletin of the Natural Historical Society of New Brunswick 18(4), 198-208.

PAlmer, A.R. 1998. A proposed nomenclature for stages and series of the Cambrian of Laurentia. Canadian Journal of Earth Sciences 35, 323-332. DOI 10.1139/e97-098

Palmer, A.R. \& Geissman, J. 1999. Geologic time scale. 1 p. Geological Society of America.

Peng, S.C. 2004. Suggested global subdivision of Cambrian System and two potential GSSPs in Hunan, China, for defining Cambrian stages, 25. In CHOI, D.K. (ed.) Korea 2004, IX International Conference on the Cambrian State Subdivision Working Group, Abstracts with Program, Taeback, Korea. School of Environmental Sciences and Institute of Geology of Geology and Environmental Sciences, Seoul National University and Palaeontological Society of Korea, Taeback.

Peng, S.C. \& BABCOCK, L.E. 2005. Towards a new global subdivision of the Cambrian System. Journal of Stratigraphy 29, 171-177, 204.

Peng, S.C. \& BABCock, L.E. 2008. Cambrian Period, 37-46. In OgG, J.G., OgG, G.J. \& Gradstein, F.M. (eds) The Concise Geologic Timescale. Cambridge University Press, Cambridge.

Peng, S.C. \& BABCOCK, L.E. 2011. Continuing progress on chronostratigraphic subdivision of the Cambrian System. Bulletin 
of Geosciences 86(3), 391-396.

DOI 10.3140/bull.geosci.1273

Peng, S.C., BABCoCK, L.E. \& Cooper, R.A. 2012. The Cambrian Period, 451-502. In Gradstein, F.M., OGG, J.G., SchmitZ, M., \& OGG, G.J. (eds) The Geologic Time Scale 2012. Elsevier, Boston.

QIAN, Y. 1977. Hyolitha and some problematics from the Lower Cambrian Meishucun Stage in Central and SW China. Acta Palaeontologica Sinica 16, 255-278.
Rozanov, A.Y. \& Missarzhevsky, V.V. 1966. Biostratigrafiya $i$ fauna nizhnich gorozontov Kembriya (Biostratigraphy and fauna of the Cambrian lower horizons). 127 pp. Akademiya Nauk SSSR, Geologicheskii Institut, Trudy 148. Nauka, Moscow.

Shergold, J. \& CoOPer, R.A. 2004. Cambrian Period, 147-164. In Gradstein, F.M., OgG, J.G. \& Smith, A. (eds) A Geological Time Scale 2004. Cambridge University Press, Cambridge. 